\title{
Araştırma Makalesi/Research Article (Original Paper) \\ Büyükbaş Hayvan Atıkları ile Sera Hasat Atıklarından Biyogaz Üretimi ve Birlikte Anaerobik Parçalanma Prosesinin Modellenmesi
}

\author{
Fatih YILMAZ ${ }^{1}$, Elçin KÖKDEMİR ÜNŞAR ${ }^{1}$, H. Emre AKMAN ${ }^{2}$, \\ N. Altınay PERENDEC I ${ }^{1 *}$, Osman YALDIZ ${ }^{2}$ \\ ${ }^{1}$ Akdeniz Üniversitesi, Mühendislik Fakültesi, Çevre Mühendisliği Bölümü, Antalya, Türkiye \\ ${ }^{2}$ Akdeniz Üniversitesi, Ziraat Fakültesi, Tarım Makineleri ve Teknolojileri Mühendisliği Bölümü, Antalya, Türkiye \\ *e-posta: aperendeci@akdeniz.edu.tr; Tel: +90 (242) 3106334
}

Özet: Bu çalışmanın amacı kök, gövde, yaprak ve meyve içeren domates ve biber bitkisi hasat atıklarının sığır gübresi ile birlikte anaerobik parçalanmasında en yüksek biyogaz veriminin elde edileceği en uygun organik yükleme ve atık karışım oranlarının saptanmasıdır. Çalışma $\% 5$ ve $\% 10$ olmak üzere 2 farklı organik yükleme miktarında gerçekleştirilmiştir. Sığır gübresi içerisine domates ve biber hasat atıkları ayrı ayrı olmak üzere \%15, $\% 30, \% 45, \% 60, \% 75$ ve $\% 90$ oranlarında karıştırılmıştır. Çalışma sonucunda en yüksek biyogaz verimi $\% 5$ organik yükleme miktarında $\% 40$ sığır gübresi ile $\% 60$ domates hasat atıkları karışım oranında elde edilmiştir. $\% 5$ ve \%10 organik yükleme miktarları için en yüksek biyogaz veriminin elde edildiği karışım oranlarına ait sonuçlar farklı kinetik modellerle (Gompertz, Cone, ve Birinci derece model) modellenmiş, kinetik modellerin deneysel verileri temsil etme yeteneği tespit edilmiş ve model parametreleri hesaplanmıştır.

Anahtar kelimeler: Anaerobik ko-fermantasyon, Biber ve domates hasat atıkları, Kinetik modelleme, Sığır gübresi

\section{Biogas Production from Cattle Manure Together with Greenhouse Harvesting Wastes and Modelling of Anaerobic Co-Digestion}

\begin{abstract}
The aim of this study is to determine the optimum organic loading and waste mixing ratios to obtain the highest biogas yield for the anaerobic digestion of tomato and pepper harvesting wastes together with cattle manure. This study was carried out at 5 and $10 \%$ of organic loadings. Tomato and pepper harvesting wastes were each mixed with cattle manure in the ratios of $15 \%, 30 \%, 45 \%, 60 \%, 75 \%$ and $90 \%$. As a result, the highest biogas yield was obtained in the mixture of $60 \%$ tomato harvesting wastes with $40 \%$ of cattle manure at $5 \%$ of organic loading. Simulation ability of each kinetic model for experimental data was determined. Results of the highest biogas yields of 5\% and $10 \%$ organic loading samples were modelled by using different kinetic models (Gompertz, Cone, and First Order) and model parameters were calculated.
\end{abstract}

Keywords: Anaerobic co-digestion, Pepper and tomato harvesting wastes, Kinetic modelling, Cattle manure

\section{Giriş}

Anaerobik parçalanma (AP) organik materyallerden enerji üretimi ve atık bertarafı için olumlu sonuçları kanıtlanmış bir teknolojidir. Organik katı atıklar (Khalid et al. 2011), arıtma çamurları (Kepp et al. 2000) ve lignoselülozik atıklar (Peces et al. 2015) metan üretimi amacıyla kullanılmaktadır. Anaerobik parçalanma teknolojisi optimum proses koşullarında çalıştırıldığında, kırsal alanda ve tarım sektöründe enerji üretiminde kullanılabileceği gibi aynı zamanda çevre koruma yöntemi olarak da önemli bir konuma sahiptir. Anaerobik teknoloji uygulamaları sera gazı salınımını azaltması yanında organik gübre üretimi de sağladığı için bitki besleme açışından da önemlidir (Defra 2009).

Anaerobik parçalanma teknolojisi farklı organik atıklardan enerji üretiminde kullanılmasına rağmen hayvan gübrelerinde bulunan yüksek amonyak/amonyum içeriği anaerobik mikroorganizmaların aktivitesini azaltmaktadır. Bu nedenle, son çalışmalar mikrobiyal aktiviteyi hızlandırmak ve biyogaz üretimini maksimize etmek için optimum proses koşullarının belirlenmesi üzerine yoğunlaşmıştır (Lindmark et al. 2014; Arıkan ve ark. 2015; Di Maria and Barratta 2015). Bu konudaki yaklaşımlardan birisi de bakteri ve arkeler için en uygun koşulların sağlanacağı organik atık karışımlarının kullanılmasıdır (Xie et al. 2011). Birlikte anaerobik parçalanma (Ko-fermantasyon) olarak adlandırılan bu yöntem ile toksik bileşiklerin seyreltilmesi, fermantasyon 
stabilizasyonunun sağlanması ve organik yükleme oranlarının artırılmasıyla besin dengesinin sağlanması ve yüksek biyogaz üretim veriminin elde edilmesi amaçlanmaktadır.

Hayvansal gübrenin anaerobik ko-fermantasyonunun biyogaz verimini artırdığı yapılan çok sayıdaki araştırma ile kanıtlanmıştır (Callaghan et al. 2002; Umetsu et al. 2006; Alvarez and Liden 2008; Saev et al. 2009). Fermantasyon sırasında bakteri ve arkeler için oldukça zengin besin maddesi içeren gübreye eklenecek karbon açısından zengin bitkisel materyal yardımıyla karbon/azot oranı dengelenerek mikroorganizmalar için daha uygun bir besin ortamı oluşturulmaktadır (Lehtomaki et al. 2007). Bununla birlikte, yüksek organik yükleme oranlarında artan uçucu organik asit miktarları anaerobik reaktör işletiminde sorun oluşturmaktadır (Ahring 1995). Bu nedenle biyogaz üretimi için en etkin organik yükleme oranlarının belirlenmesi önem taşımaktadır.

Domates (Lycopersicon esculentum) ve biber (Capsicum annuит L.) bitkileri dünyada birçok ülkede yetiştirilmektedir. Türkiye, elverişli iklim koşulları nedeniyle her iki ürünün de üretiminde büyük bir paya sahiptir. Bu yüksek miktarlardaki üretim, bertarafı gereken hasat atıkları problemini de beraberinde getirmektedir. Bu iki ürünün atıkları diğer tarımsal ürün atıkları gibi düzensiz bertaraf edilmektedir. Yol kenarlarına dökme, kontrolsüz yakma gibi uygulamalar önemli çevre sorunlarına neden olmaktadır (Us ve Perendeci 2012).

$\mathrm{Bu}$ çalışmanın amacı; domates ve biber hasat atıklarının sığır gübresi ile ko-fermantasyonunda en yüksek biyogaz veriminin elde edileceği organik yükleme miktarları ve atık karışım oranlarının saptanmasıdır. Bu kapsamda çalışma $\% 5$ ve $\% 10$ olmak üzere 2 farklı organik yükleme miktarında ve $35^{\circ} \mathrm{C}$ reaksiyon sıcaklığı koşullarında gerçekleştirilmiştir. Sığır gübresi içerisine domates ve biber hasat atıkları ayrı ayrı olmak üzere $\% 15,30,45,60,75$ ve 90 oranlarında karıştırılmıştır. Her iki organik yükleme miktarında en yüksek biyogaz veriminin elde edildiği karışım oranlarındaki deneysel sonuçlar farklı kinetik modellerle (Gompertz, Cone ve Birinci Derece) karşılaştırılarak kinetik modellerin deneysel verileri temsil etme yeteneği tespit edilmiş ve model parametreleri hesaplanmıştır.

\section{Materyal ve Yöntem}

\section{Hasat Atık Numunelerinin Temin Edilmesi ve Karakterizasyon Analizleri}

Akdeniz Üniversitesi, Ziraat Fakültesinde bulunan seralardan, domates ve biber bitkilerine ait kök, gövde, yaprak ve meyve içeriklerini temsil edecek şekilde hasat atığı numuneleri alınmış ve numunelerin boyutları küçültülerek $-20^{\circ} \mathrm{C}$ 'de muhafaza edilmiştir. Hayvan gübresi ise Akdeniz Üniversitesi, Hayvancılık İşletmesinden alınmış ve $-20^{\circ} \mathrm{C}$ 'de muhafaza edilmiştir. Atık karakterizasyonunun belirlenmesi amacıyla toplam katı madde (TKM), uçucu katı madde (UKM), toplam kimyasal oksijen ihtiyacı (tKOİ), çözünmüss kimyasal oksijen ihtiyacı (çKOI), toplam ve indirgen şeker, protein ile Van Soest fraksiyon analizleri yapılmıştır. Toplam katı madde (TKM) ve uçucu katı madde (UKM) analizleri Standard Methods 2540'a (APHA 2005) ve toplam kimyasal oksijen ihtiyacı (tKOİ) analizleri Standard Methods 5220-B'ye (APHA 2005) göre yapılmıştır. Çözünmüş kimyasal oksijen ihtiyacı (çKOI) chromosulfuric acid (DIN 38409 H41, ISO 6060-1989) metodu ve Hach Lange COD kitleri ile Hach-Lange DR5000 spektrofotometre kullanılarak yapılmıştır. Toplam ve indirgen şeker analizleri DNS metoduna (Miller 1959) ve protein analizleri Lowry (1951) metoduna göre yapılmıştır. Selüloz, hemiselüloz ve lignin içerikleri ise Van Soest (1963) metoduna göre belirlenmiş̧ir.

\section{Biyokimyasal Metan Potansiyeli (BMP) Testi}

Ko-fermantasyonun biyogaz üretim verimine olan etkisinin belirlenmesi amaciyla Carrere ve ark. (2009) ile Us ve Perendeci (2012) tarafindan uygulanan standart yönteme göre BMP testleri gerçekleştirilmiştir. Anaerobik aş1 çamuru Hurma atıksu arıtma tesisi anaerobik çamur çürütme ünitesinden alınmıştır. BMP şişesi içerisindeki aktif aş1 konsantrasyonu $3 \mathrm{~g} \mathrm{UKM} / \mathrm{L}$ ve substrat-aş1 oranı ise $0,5 \mathrm{~g} \mathrm{UKM} / \mathrm{g}$ UKM olarak ayarlanmıştır. Aşı aktivitesinin sağlanması amacıyla BMP şişelerine Çizelge 1'de sunulan makro ve mikro elementler ilave edilmiştir. İnkübasyon öncesinde şişelerin içerisinden $\% 70 \mathrm{~N}_{2}$ ve $\% 30 \mathrm{CO}_{2}$ gaz karışımı geçirilerek anaerobik koşulların oluşması sağlanmıştır. BMP testleri mezofilik $\left(35^{\circ} \mathrm{C}\right)$ şartlarda yürütülmüşșirr. BMP analizinin yapıldığı BMP şişelerinde oluşan biyogaz miktarı belirli günlerde gaz-sıvı yer değiştirme prensibiyle çalışan gaz ölçüm sistemi kullanılarak ölçülmüştür. BMP testinde biyogaz içindeki gaz bileşenleri $\left(\mathrm{CH}_{4}\right.$ ve $\left.\mathrm{CO}_{2}\right) \mathrm{PPQ}$ kolona (10 m) sahip Varian CP 4900 Micro Gaz Kromatografi ile tespit edilmiştir. 
Çizelge 1. Makro ve mikro elementler

\begin{tabular}{lc}
\hline Makro Elementler & $\begin{array}{c}\text { Konsantrasyon } \\
(\mathbf{m g} / \mathbf{L})\end{array}$ \\
\hline $\mathrm{NH}_{4} \mathrm{Cl}$ & 172 \\
$\mathrm{KH}_{2} \mathrm{PO}_{4}$ & 65 \\
$\mathrm{MgCl}_{2} \cdot 6 \mathrm{H}_{2} \mathrm{O}$ & 39 \\
$\mathrm{CaCl}_{2} \cdot 2 \mathrm{H}_{2} \mathrm{O}$ & 19 \\
\hline $\mathbf{M i k r o ~ E l e m e n t l e r ~}$ & Konsantrasyon \\
& (mg/L) \\
\hline $\mathrm{FeCl}_{2} \cdot 4 \mathrm{H}_{2} \mathrm{O}$ & 20 \\
$\mathrm{CoCl}_{2} \cdot 6 \mathrm{H}_{2} \mathrm{O}$ & 5 \\
$\mathrm{MnCl}_{2} \cdot 4 \mathrm{H}_{2} \mathrm{O}$ & 1 \\
$\mathrm{NiCl}_{2} \cdot 6 \mathrm{H}_{2} \mathrm{O}$ & 1 \\
$\mathrm{ZnCl}_{2}$ & 0,5 \\
$\mathrm{H}_{3} \mathrm{BO}_{3}$ & 0,5 \\
$\mathrm{Na}_{2} \mathrm{SeO}_{3}$ & 0,5 \\
$\mathrm{CuCl}_{2} \cdot 2 \mathrm{H}_{2} \mathrm{O}$ & 0,4 \\
$\mathrm{Na}_{2} \mathrm{MoO}_{4} \cdot 2 \mathrm{H}_{2} \mathrm{O}$ & 0,1 \\
\hline
\end{tabular}

\section{Kinetik Modelleme}

Bu çalışmada ko-substratların etkilerini değerlendirmek için kinetik modellerden faydalanılmıştır. Bu kapsamda, Gompertz modeli (Lay et al. 1997), Cone modeli (Pitt et al. 1999) ve Birinci Derece kinetik model (LlabresLuengo and Mata-Alvarez 1987) ile ko-fermantasyon değerlendirilmiştir. Biyogaz üretim potansiyeli $(P)$, maksimum metan üretim hızı $\left(R_{M}\right)$ ve lag fazı süresi $(\lambda)$ Gompertz modeli ile hesaplanmıştır. Hidroliz hız sabitinin $\left(k_{h}\right)$ belirlenmesi amacıyla Birinci Derece kinetik model uygulanmıştır. Cone modeli yardımıyla birinci derece hız sabiti $\left(k_{c}\right)$ ve şekil faktörü $(n)$ tespit edilmiştir. Yapılan çalışmada hızlı ayrışan ve yavaş ayrışan maddelerin biyogaz üretimine etkisinin daha doğru belirlenmesi amacıyla Kim et al. (2003) ve Akman ve ark. (2015) tarafından uygulanan model modifikasyonu kullanılmıştır. Bu nedenle hızlı ve yavaş ayrışan maddeleri temsil etmesi için ayrı ayrı katsayılar belirlenmiştir. Model simülasyonları AQUASIM 2.0 programı kullanılarak yapılmıştır (Reichert et al. 1998). Ko-fermantasyon performansının değerlendirilmesinde kullanılan model eşitlikleri Çizelge 2'de verilmiştir.

Çizelge 2. Ko-fermantasyon performansının değerlendirilmesinde kullanılan model eşitlikleri

\begin{tabular}{ll}
\hline Model & Eşitlikler \\
$\begin{array}{l}\text { Gompertz } \\
\text { Modeli }\end{array}$ & $M_{P}=P_{M 1} \exp \left(-\exp \left[\frac{R_{M 1} \times e}{P_{M 1}}\left(\lambda_{1}-t\right)+1\right]\right)+P_{M 2} \exp \left(-\exp \left[\frac{R_{M 2} \times e}{P_{M 2}}\left(\lambda_{2}-t\right)+1\right]\right)$ \\
$\begin{array}{l}\text { Cone } \\
\text { Modeli }\end{array}$ & $M p=P_{M 1} /\left[1+\left(k_{c 1} t\right)^{-n 1}\right]+P_{M 2} /\left[1+\left(k_{c 2} t\right)^{-n 2}\right]$ \\
$\begin{array}{l}\text { Birinci Derece } \\
\text { Model }\end{array}$ & $M_{P}=P_{M 1}\left(1-\exp \left[-k_{h 1} \times t\right]\right)+P_{M 2}\left(1-\exp \left[-k_{h 2} \times t\right]\right)$ \\
\hline
\end{tabular}

\section{Bulgular ve Tartış̧a}

\section{Hasat Atıkları ve Siğır Gübresi Karakterizasyon Sonuçları}

Domates ve biber hasat atıkları ile sığır gübresine ait karakterizasyon analiz sonuçları Çizelge 3'te verilmiştir. Atık karakterizasyon analizlerinde yaş numune ile çalışılmıştır. Çizelge 3'ten görüleceği üzere domates ve biber hasat atıkları ile sığır gübresinin TKM değerleri sırasıyla \%15,87, 12,84, 19,37 ve UKM değerleri \% 13,24, 10,43 ve 14,96 olarak ölçülmüştür.

tKOİ değerleri incelendiğinde en yüksek değerin sığır gübresinden elde edildiği görülmektedir. Van Soest fraksiyonu açısından değerlendirildiğinde ise en yüksek selüloz ve hemiselüloz miktarı sığır gübresinde tespit edilmiştir. 
Çizelge 3. Domates ve biber hasat atıkları ile sığır gübresi atık karakterizasyon analiz sonuçları

\begin{tabular}{lccc}
\hline Parametre & $\begin{array}{c}\text { Domates Hasat Atıkları } \\
\text { (DA) }\end{array}$ & $\begin{array}{c}\text { Biber Hasat Atıkları } \\
\text { (BA) }\end{array}$ & $\begin{array}{c}\text { Sığır Gübresi } \\
\text { (SG) }\end{array}$ \\
\hline TKM (gTKM/kgNumune) & 158,77 & 128,43 & 193,70 \\
UKM (gUKM/kgNumune) & 132,44 & 104,35 & 149,64 \\
tKOİ (mgKȮ்/gUKM) & 561,57 & 1154,14 & 2072,93 \\
çKOİ (mgKOİ/gUKM) & 301,17 & 258,70 & 300,72 \\
tŞeker (mgGlukoz/gUKM) & 129,76 & 92,54 & 590,14 \\
çŞeker (mgGlukoz/gUKM) & 43,80 & 69,39 & 56,20 \\
Protein (mgPro/gUKM) & 280,75 & 416,50 & 320,05 \\
Van Soest Fraksiyonu & & & 5,58 \\
Selüloz (\%) & 1,31 & 2,17 & 3,90 \\
Hemiselüloz (\%) & 1,23 & 2,41 & 87,88 \\
Çözünmüş Madde (\%) & 95,80 & 93,58 & 2,63 \\
Lignin (\%) & 1,66 & 1,84 & \\
\hline
\end{tabular}

Siğır Gübresinin (SG) Anaerobik Parçalanabilirliği

Sığır gübresinin tek başına anaerobik parçalanması sonucu elde edilen biyokimyasal metan potansiyelini belirlemek için $\% 5$ ve $\% 10$ organik yükleme miktarlarında BMP testi yapılmıştır. Kümülatif metan üretim miktarları, toplam numunenin metan üretim değerlerinden aşı çamurundan üretilen metan üretim miktarının çıkarılmasıyla hesaplanmıştır. Şekil 1 'de $\% 5$ ve $\% 10$ organik yükleme miktarlarında sığır gübresinin BMP değerleri verilmiştir. Şekil 1'den görüleceği üzere kümülatif metan üretimi, organik yükleme miktarı \% 5 'ten \%10'a çıkarıldığında artış göstermiştir. BMP değerleri \%5 ve \%10 organik yükleme miktarlarında sırasıyla 104,1 ve $111,1 \mathrm{mLCH}_{4} / \mathrm{gUKM}$ olarak tespit edilmiştir.

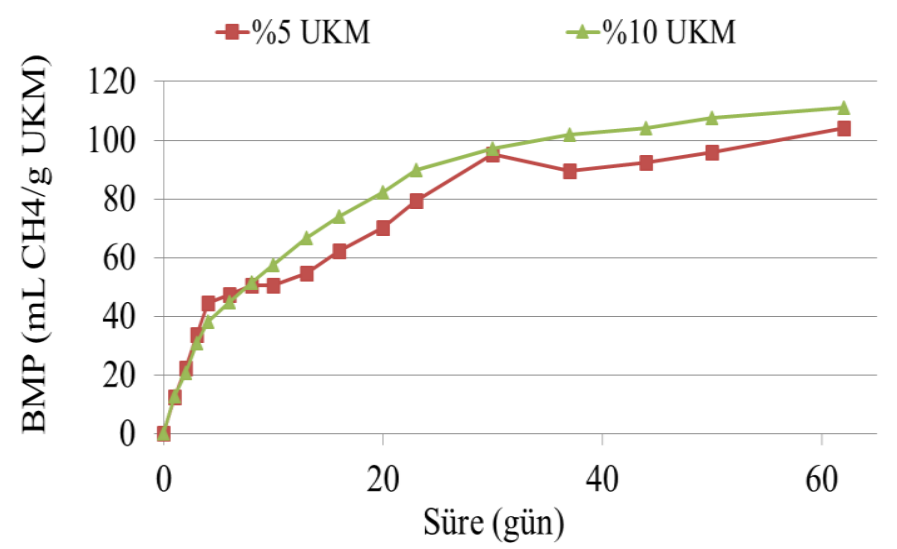

Şekil 1. \%5 ve \%10 organik yükleme içeren sı̆̆ır gübresinin BMP değerleri.

\section{Sığır Gübresi (SG) ile Domates Hasat Atıklarının (DA) Anaerobik Ko-fermantasyonu}

$\% 5$ ve \%10 organik yükleme miktarlarında optimum karışım oranını belirlemek amacıyla organik yükleme temelinde sı̆̆ır gübresi içerisine $\% 15, \% 30, \% 40, \% 55, \% 75$ ve $\% 90$ oranlarında domates hasat atıkları eklenmiştir. Şekil 2 (a) ve (b)'de \%5 ve \%10 organik yükleme miktarlarında sığır gübresi ve domates hasat atıklarının anaerobik ko-fermantasyon sonucu üretilen BMP değerlerinin zamanla değişimi verilmektedir. Şekil 2 'den görüleceği üzere en yüksek BMP değerleri $\% 5$ ve $\% 10$ organik yükleme miktarlarında $\% 60$ domates hasat atıkları ve \%40 sığır gübresi içeren karışım numunelerinden sırasıyla 260,8 $\mathrm{mLCH}_{4} / \mathrm{gUKM}$ ve 141,7 $\mathrm{mLCH}_{4} / \mathrm{gUKM}$ olarak elde edilmiştir. \%5 organik yükleme miktarında üretilen metan, sığır gübresinin tek başına anaerobik parçalanmasından elde edilen metandan \%150,5 daha fazladır. 


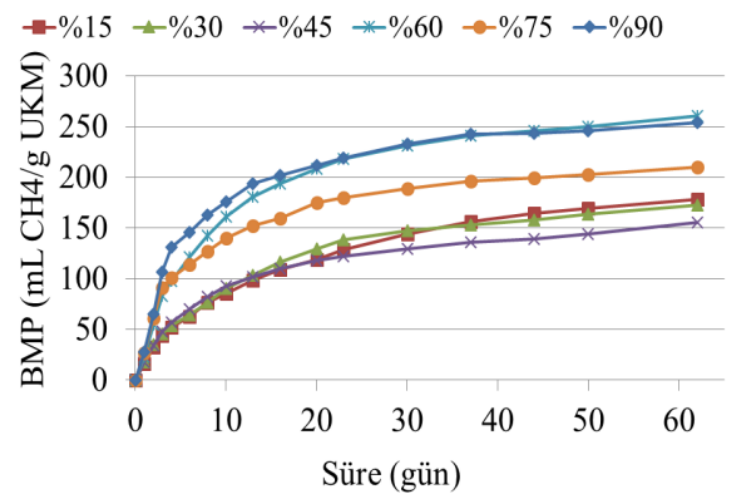

(a)

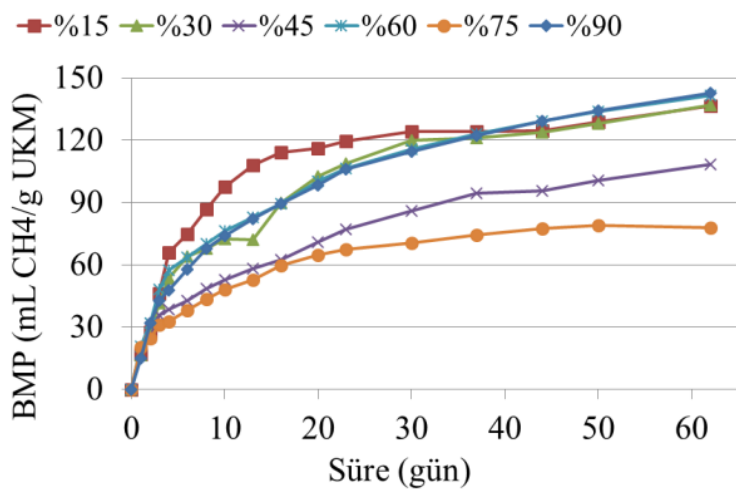

(b)

Şekil 2. \%5 (a) ve \%10 (b) organik yükleme miktarlarında zamana bağlı olarak sı̆̆ır gübresi ile domates hasat atıklarının anaerobik ko-fermantasyonu sonucunda üretilen kümülatif BMP değerleri.

\section{Sığır Gübresi (SG) ile Biber Hasat Atıklarının (BA) Anaerobik Ko-fermantasyonu}

$\% 5$ ve \%10 organik yükleme miktarlarında optimum karışım oranını belirlemek amacıyla organik yükleme temelinde sı ̆̆ır gübresi içerisine $\% 15, \% 30, \% 40, \% 55, \% 75$ ve $\% 90$ oranlarında biber hasat atıkları eklenmiştir. Şekil 3 (a) ve (b)'de \%5 ve \%10 organik yükleme miktarlarında sığır gübresi ve biber hasat atıklarının anaerobik ko-fermantasyonu sonucu üretilen BMP değerlerinin zamanla değişimi verilmiştir. Şekil 3 'ten görüleceği üzere en yüksek BMP değerleri $\% 5$ ve $\% 10$ organik yükleme miktarlarında; $\% 90$ ve $\% 60$ biber hasat atıkları ve $\% 10$ ve \%40 sı̆̆ır gübresi içeren karışımlardan elde edilmiştir. BMP değerleri \%5 organik yükleme miktarında (90:10 BA:SG) ve \%10 organik yükleme miktarında (60:40 BA:SG) sırasıyla 221,1 $\mathrm{mLCH}_{4} / \mathrm{gUKM}$ ve 242,4 $\mathrm{mLCH}_{4} / \mathrm{gUKM}$ olarak elde edilmiştir. \%10 organik yükleme miktarında üretilen metan, sığır gübresinin tek başına anaerobik parçalanmasından elde edilen metandan \%118,2 daha fazladır.

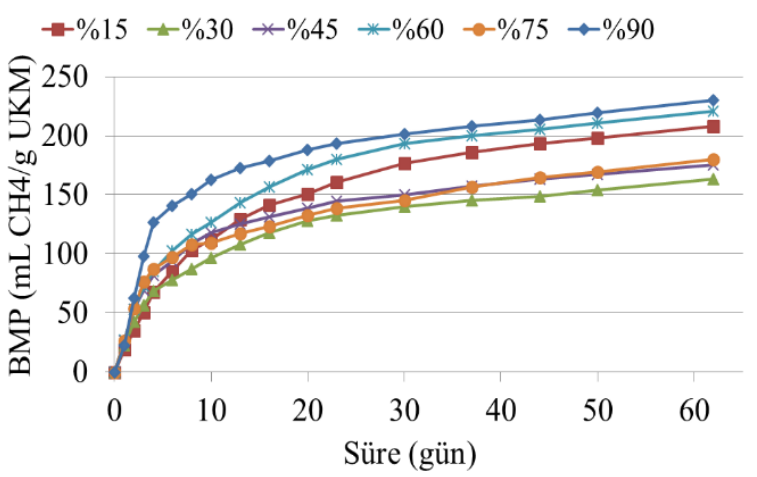

(a)

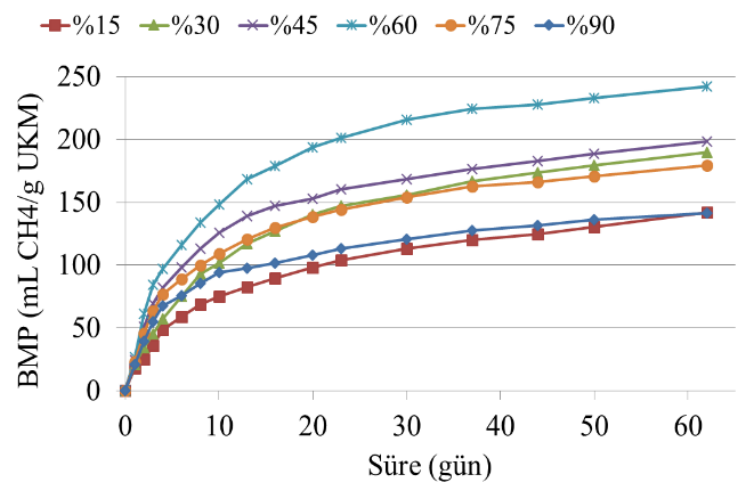

(b)

Şekil 3. \%5 (a) ve \%10 (b) organik yükleme miktarlarında zamana bağlı olarak sığır gübresi ile biber hasat atıklarının anaerobik ko-fermantasyonu sonucunda üretilen kümülatif BMP değerleri.

\section{Anaerobik Ko-fermantasyon Kinetik Modelleme Sonuçlarının Değerlendirilmesi}

BMP testleri sonucunda en yüksek biyogaz veriminin elde edildiği karışım oranlarına ait deney sonuçları farklı modeller ile incelenmiştir. Bu kapsamda, $\% 5$ organik yükleme miktarında $\% 60$ domates hasat atıkları ve $\% 40$ sığır gübresi içeren numune ile $\% 10$ organik yükleme miktarında $\% 60$ biber hasat atıkları ve $\% 40$ sığır gübresi içeren numuneye ait deneysel sonuçlar Gompertz modeli (Lay et al. 1997), Cone modeli (Pitt et al. 1999) ve Birinci Derece kinetik model (Llabres-Luengo and Mata-Alvarez 1987) ile modellenmiştir. Sığır gübresinin, domates ve biber hasat atıkları ile ko-fermantasyonu sonucunda yapılan kinetik modellerden elde edilen parametre değerleri Çizelge 4'te verilmiştir.

Domates ve biber hasat atıklarının sığır gübresi ile ko-fermantasyonu için uygulanan üç kinetik model için de yüksek determinasyon katsayıları $\left(R^{2}\right)$ elde edilmiştir. Kinetik modellerden elde edilen sonuçlar birbiri ile tutarlılık göstermektedir. Kinetik modellerin uygulanması sonucunda elde edilen BMP profilleri Şekil 4'te 
sunulmuştur. Şekil 4'ten hem domates hasat atıkları hem de biber hasat atıklarının sığır gübresi ile kofermantasyonu sonucu elde edilen deneysel BMP verilerinin her 3 kinetik modelden elde edilen BMP profilleri ile uyumlu olduğu görülmektedir. Çizelge 4 'teki değerler incelendiğinde; $\% 5$ organik yükleme içeren karışımda hızlı ayrışan maddeler için gecikme fazının $\left(\lambda_{1}: 0,03\right)$ yavaş ayrışan maddelerin gecikme fazına $\left(\lambda_{2}: 1,86\right)$ göre oldukça farklı olduğu görülmüştür. Gompertz modelinden elde edilen metan üretim hızları incelendiğinde de hızlı ayrışan maddelerin metan üretim hızının $\left(R_{M}: 21,09\right)$ daha yüksek olduğu görülmektedir. \%5 organik yükleme içeren karışım için her 3 modelde de hızlı ayrışan maddelerden elde edilen biyogaz miktarları $\left(\mathrm{BMP}_{1}\right)$ yavaş ayrışan maddelerden $\left(\mathrm{BMP}_{2}\right)$ daha yüksek olarak bulunmuştur. Cone modeli $(0,50 / 0,07)$ ve Birinci Derece modelde de $(0,19 / 0,04)$ hidroliz sabitleri arasındaki fark hızlı ve yavaş ayrışan maddelerden elde edilen biyogaz miktarları arasındaki farkı desteklemektedir. \%10 organik yükleme içeren karışımda ise hızlı ayrışan maddelerden elde edilen biyogaz miktarının daha düşük olduğu belirlenmiştir. Gompertz modelinden elde edilen metan üretim hızı değerlerine bakıldığında organik maddenin büyük kısmının yavaş ayrışabilir olduğu görülmektedir. Domates hasat atıkları içeren \%5 organik yükleme karışımıyla karşılaştırıldığında, biber hasat atıkları içeren $\% 10$ organik yükleme karışımında hızlı ayrışabilir ve yavaş ayrışabilir maddelerin gecikme fazlarında $(0,25 / 0,53)$ çok daha az bir farklılık görülmüştür. \%10 organik yükleme içeren karışımda; Cone ve Birinci Derece model birbirine yakın biyogaz değerleri hesaplarken, Gompertz modelinde hızlı ayrışan atıklara ait biyogaz miktarı daha düşük hesaplanmıştır.

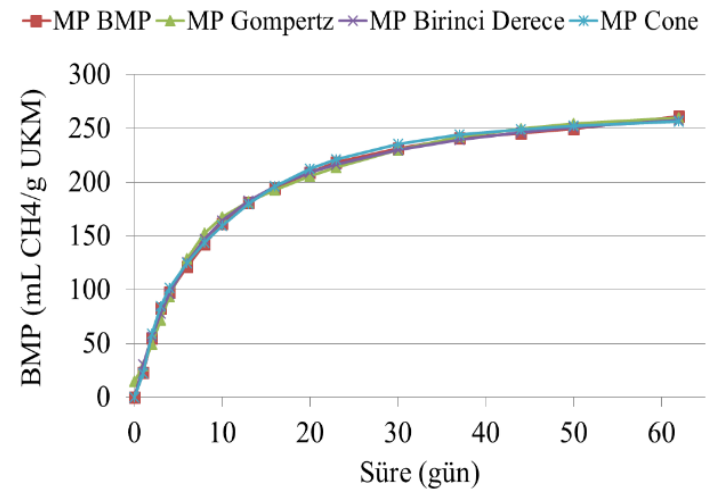

(a)

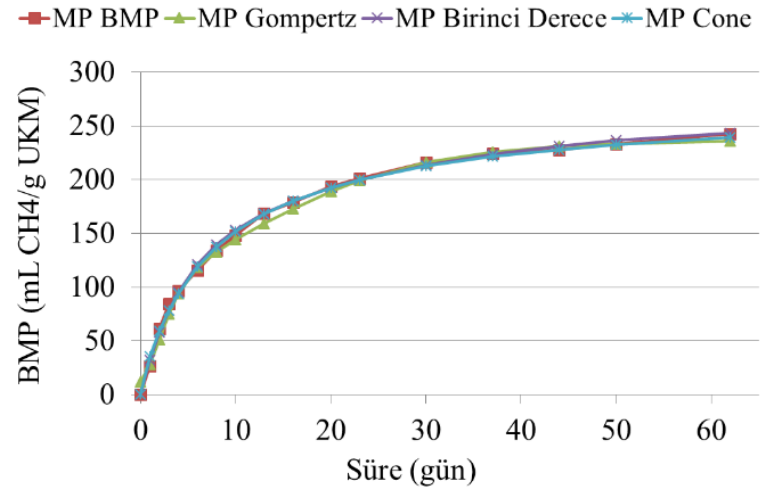

(b)

Şekil 4. (a) \%5 organik yükleme - \%60 domates hasat atıkları ile \%40 sığır gübresi karışım oranında ve (b) \%10 organik yükleme - \%60 biber hasat atıkları ile \%40 sığır gübresi karışım oranında deneysel ve kinetik modellerden elde edilen BMP profilleri.

Çizelge 4. Kinetik modelleme sonuçları

$\begin{array}{cc}\text { \%5 Organik Yükleme } & \% 10 \text { Organik Yükleme } \\ \% 60 \text { DA + \%40 SG } & \% 60 \text { BA + \%40 SG }\end{array}$

\begin{tabular}{|c|c|c|c|c|c|c|}
\hline Parametre & Gompertz M. & Cone M. & $\begin{array}{c}\text { Birinci } \\
\text { Derece } \mathrm{M} \text {. }\end{array}$ & $\begin{array}{l}\text { Gompertz } \\
\text { M. }\end{array}$ & Cone M. & $\begin{array}{c}\text { Birinci } \\
\text { Derece M. }\end{array}$ \\
\hline $\begin{array}{l}\mathrm{BMP}_{1} \\
\left(\mathrm{mLCH}_{4} / \mathrm{gUKM}\right)\end{array}$ & 152,3 & 154,9 & 146,1 & 98,9 & 117,3 & 114,8 \\
\hline $\begin{array}{l}\mathrm{BMP}_{2} \\
\left(\mathrm{mLCH}_{4} / \mathrm{gUKM}\right)\end{array}$ & 111,1 & 109,6 & 123,2 & 137,6 & 139,8 & 139,7 \\
\hline $\begin{array}{l}R_{M 1} / R_{M 2} \\
\left(\mathrm{mLCH}_{4} / \mathrm{gUKM} . \mathrm{g}\right)\end{array}$ & $21,09 / 2,94$ & & & $13,16 / 2,91$ & & \\
\hline$\lambda_{1} / \lambda_{2}(g)$ & $0,03 / 1,86$ & & & $0,25 / 0,53$ & & \\
\hline$k_{h 1} / k_{h 2}$ & & & $0,19 / 0,04$ & & & $0,26 / 0,04$ \\
\hline$k_{c 1} / k_{c 2}$ & & $0,50 / 0,07$ & & & $0,08 / 0,25$ & \\
\hline$n_{1} / n_{2}$ & & $2,06 / 1,93$ & & & $1,14 / 1,14$ & \\
\hline$R^{2}$ & 0,994 & 0,999 & 0,998 & 0,995 & 0,998 & 0,998 \\
\hline
\end{tabular}

1: Hızlı ayrıșan maddeler

2:Yavaş ayrışan maddeler

\section{Sonuç}

Bu çalışmanın amacı domates ve biber hasat atıklarının sığır gübresi ile ko-fermantasyonunda en yüksek biyogaz veriminin elde edileceği organik yükleme miktarlarının ve atık karışım oranlarının saptanmasıdır. Çalışmada \%5 
ve \%10 olmak üzere iki farklı organik yükleme miktarı incelenmiştir. İki farklı organik yükleme miktarında sığır gübresinin içerisine 6 farklı karışım oranında ( $\% 15, \% 30, \% 45, \% 60, \% 75, \% 90)$ ayrı ayrı biber ve domates hasat atıkları eklenerek ko-fermantasyonları incelenmiştir. BMP testleri sonucunda $\% 5$ organik yükleme miktarında $\% 60$ domates hasat atıkları ile $\% 40$ sığır gübresi karışım oranında ve $\% 10$ organik yükleme miktarında $\% 60$ biber hasat atıkları ile \%40 sığır gübresi karışım oranında en yüksek BMP değerleri elde edilmiş̧ir.

Domates hasat atıkları için $\% 5$ organik yükleme miktarında üretilen metan miktarı, sığır gübresinin tek başına anaerobik parçalanmasından elde edilen metan miktarından \%150,6 daha fazladır. Biber hasat atıkları için ise $\% 10$ organik yükleme miktarında üretilen metan miktarı, sığır gübresinin tek başına anaerobik parçalanmasından elde edilen metan miktarından \%118,08 daha fazladır. Kinetik modeller proseslerin gerçek ölçekte uygulanabilirliği hakkında uygulayıcılar için önemli bilgiler sağlamaktadır. Bu amaçla bu çalışmada deneysel BMP değerleri yüksek determinasyon katsayıları elde edilerek $\left(R^{2} \geq 0,99\right)$ farklı kinetik modeller ile modellenmiş ve modellere ait parametre değerleri tespit edilmiştir. Elde edilen sonuçlar her üç modelin uygulanabilir olduğunu göstermektedir. Elde edilen kümülatif BMP test sonuçları ve matematiksel modellerden elde edilen sonuçlar sığır gübresi ile domates ve biber hasat atıklarının birlikte anaerobik ko-fermantasyonunun uygun olduğunu göstermektedir. Sığır gübresi ile sera hasat atıklarından biyogaz üretimine ait kinetik model katsayılarının belirlenmesi ile gerçek ölçekte sığır gübresi ve sera hasat atıklarından anaerobik ko-fermantasyon prosesini uygulamak isteyen uygulayıcıların ekonomik bir tesis dizayn edebilmelerinin mümkün olduğu görülmektedir. Kinetik parametrelerden yola çıkarak en uygun fermantasyon süresi belirlenebilecek ve tesis boyutlandırması yapılabilecektir.

\section{Teşekkür}

Bu araştırma projesi (FBA-2015-579), Akdeniz Üniversitesi Bilimsel Araştırma Projeleri Koordinasyon Birimi tarafindan desteklenmiştir.

\section{Kaynaklar}

Ahring BK, Sandberg M, Angelidaki I (1995). Volatile fatty acids as indicators of process imbalance in anaerobic digestors. Appl. Microbiol. Biotechnol. 43: 559.

Akman HE, Akman E, Ciggin AS, Perendeci NA, Yaldiz O (2015). Effects of mixture ratio of cow manure and greenhouse wastes on anaerobic co-digestion process. Agric. Eng. Int.:CIGR Journal 160-167.

Alvarez R, Liden G (2008). Anaerobic co-digestion of aquatic flora and quinoa with manures from Bolivian Altiplano. Waste Management 28: 1933-1940.

APHA (2005). Standard Methods for the Examination of Water and Wastewater. American Public Health Association.

Arıkan OA, Mulbry W, Lansing S (2015). Effect of temperature on methane production from field-scale anaerobic digesters treating dairy manure. Waste Management 43: 108-113.

Callaghan FJ, Wase DA, Thayanithy K, Forster CF (2002). Continuous co-digestion of cattle slurry with fruit and vegetable wastes and chicken manure. Biomass and Bioenergy 27: 71-77.

Carrere H, Sialve B, Bernet N (2009) Improving Pig Manure into Biogas by Thermal and Thermo-Chemical Pretreatments. Bioresource Technol. 100: 3690-3694.

Defra (2009). Anaerobic Digestion - Shared Goals. Department for Environment, Food and Rural Affairs, UK. http://www.biogen.co.uk/upload/item/page30/file/ad-sharedgoals-090217(1).pdf. (Erişim tarihi: 15 Ekim, 2017).

Di Maria F, Barratta M (2015). Boosting methane generation by co-digestion of sludge with fruit and vegetable waste: Internal environment of digester and methanogenic pathway. Waste Management 43: 130-136.

Kepp U, Machenbach I, Weisz N, Solheim OE (2000). Enhanced stabilisation of sewage sludge through thermal hydrolysis - three years of experiencewith full scale plant. Water Science and Technology 42 (9): 8996.

Khalid A, Arshad M, Anjum M, Mahmood T, Dawson L (2011). The anaerobic digestion of solid organic waste. Waste Management 31: 1737-1744.

Kim H, Han S, Shin H (2003). The optimization of food waste as a co-substrate in anaerobic digestion of sewage sludge. Waste Manage. Res. 21: 515-526.

Lay JJ, Li Y, Noike T (1997). Influence of $\mathrm{pH}$ and moisture content on the methane production in high-solids sludge digestion. Water Research 31: 1518-1524.

Lehtomaki A, Huttunen S, Rintala JA (2007). Laboratory investigations on co-digestion of energy crops and crop residues with cow manure for methane production: Effect of crop to manure ratio. Resources, Conservation and Recycling 51: 591-609. 
Lindmark J, Eriksson P, Thorin E (2014). The effects of different mixing intensities during anaerobic digestion of the organic fraction of municipal solid waste. Waste Management 34 (8): 1391-1397.

Llabres-Luengo P, Mata-Alvarez J (1987). Kinetic study of the anaerobic digestion of straw-pig manure mixtures. Biomass 14 (2): 129-142.

Lowry OH, Rosebrough NJ, Fau AL, Randall RJ (1951). Protein measurement with the Folin reagent. J. of Bio. Chem. 193: 265-275.

Miller GL (1959). Use of dinitrosalicylic acid reagent for determination of reducing sugar. Anal. Chem. 31: 426428.

Peces M, Astals S, Mata-Alvarez J (2015). Effect of moisture on pretreatment efficiency for anaerobic digestion of lignocellulosic substrates. Waste Management 46: 189-196.

Pitt RE, Cross TL, Pell AN, Schofield P, Doane PH (1999). Use of in vitro gas production models in ruminal kinetics. A. H. Biosci. 159: 145-163.

Reichert P, Ruchti J, Simon W (1998). Aquasim 2.0. Swiss Federal Institute for Environmental Science and Technology (EAWAG), CH-8600 Duebendorf, Switzerland.

Saev M, Koumanova B, Simeonov IV (2009). Anaerobic co-digestion of wasted tomatoes and cattle dung for biogas production. J. of the Univ. of Chemical Technology and Metallurgy 44, 1: 55-60.

Umetsu K, Yamazakı S, Kıshımoto T, Takahashı J, Shıbata Y, Zhang C, Misakı T, Hamamoto O, Ihara I, Komiyama M (2006). Anaerobic co-digestion of dairy manure and sugar beets. International Congress Series 1293: 307-310.

Us E, Perendeci A (2012). Improvement of Methane Production from Greenhouse Residues: Optimization of Thermal and $\mathrm{H}_{2} \mathrm{SO}_{4}$ Pretreatment Process by Experimental Design. Chemical Engineering Journal 181182: 120-131.

Xie S, Lawlor PG, Frost JP, Hu Z, Zhan X (2011). Effect of pig manure to grass silage ratio on methane production in batch anaerobic co-digestion of pig manure and grass silage. Bioresource Technology 102 (10): 5728-5733. 